\title{
Biventricular centrimag support for patients in end-stage biventricular heart failure
}

\author{
V Horvath ${ }^{\text {* }}$, P Nemec ${ }^{1}$, J Ondrasek ${ }^{2}$, H Bedanova ${ }^{1}$, J Slavik², P Pokorny ${ }^{2}$, P Pavlik², M Orban ${ }^{1}$ \\ From 23rd World Congress of the World Society of Cardio-Thoracic Surgeons \\ Split, Croatia. 12-15 September 2013
}

\section{Background}

The CentriMag mechanical support device (Levitronix LLC, Waltham, USA) is intended for short-term paracorporeal circulatory support in patients in refractory cardiogenic shock. The paper presents our experience with this device allowing urgent initiation of biventricular circulatory support.

\section{Methods}

From December 2009 through October 2012, the CentriMag device was implanted in 11 patients ( 2 women) transferred to our institution with refractory biventricular end-stage heart failure and multisystem organ failure. The mean age of our patients was $46.5 \pm 12.0$ years (range, 20-64 years). The basic cardiac disease was dilated cardiomyopathy (7 patients), myocarditis ( 2 patients) and coronary artery disease (2 patients).

\section{Results}

The mean ventricular support time was $26.9 \pm 16.5$ days (range, $11-71$ days). In six patients (55\%), mechanical support was completed with heart transplantation. Recovery of heart function occurred in two (18\%) patients. Three (27\%) patients died while on the support device. The 30-day and one-year survival rates were $64 \%$ (7 patients) and 55\% (6 patients), respectively. The mean time from support device implantation to putting the patient on the waiting list was $13.4 \pm 20.5$ days (range, 0 57 days) depending on recovery of organ (including the CNS) function. The mean waiting time was $14.6 \pm$ 11.3 days (range, $3-35$ days). The three-month and oneyear survival rates after heart transplantation were $83 \%$ and $67 \%$ ( 4 of 6 patients), respectively.

\footnotetext{
* Correspondence: vladimir.horvath@seznam.cz

'International Clinical Research Centre, St. Anne's University Hospital, Brno, Czech Republic

Full list of author information is available at the end of the article
}

\section{Conclusion}

The installation of the Levitronix CentriMag device in our center resulted in a marked improvement of an otherwise grim prognosis of patients whose anticipated survival rates, unless undergoing urgent mechanical cardiac support implantation would be in the order of hours, or several days at most.

\section{Authors' details}

'International Clinical Research Centre, St. Anne's University Hospital, Brno, Czech Republic. ${ }^{2}$ Centre for Cardiovascular and Transplant Surgery, Brno, Czech Republic.

Published: 11 September 2013

\section{doi:10.1186/1749-8090-8-S1-0146}

Cite this article as: Horvath et al:: Biventricular centrimag support for patients in end-stage biventricular heart failure. Journal of Cardiothoracic Surgery 2013 8(Suppl 1):0146.
Submit your next manuscript to BioMed Central and take full advantage of:

- Convenient online submission

- Thorough peer review

- No space constraints or color figure charges

- Immediate publication on acceptance

- Inclusion in PubMed, CAS, Scopus and Google Scholar

- Research which is freely available for redistribution

Submit your manuscript at www.biomedcentral.com/submit
C Bïomed Central

\section{() Biomed Central}

